http://nv.nltu.edu.ua

https://doi.org/10.15421/40280309

Article received 27.03.2018 p.

Article accepted 26.04.2018 p.

удк 630*582.475.2:165.7

@ $\triangle$ Correspondence author

T. I. Kharachko

taras-forester@ukr.net

Р. I. Мандзюк'1, Т. I. Харачко

${ }^{1}$ Галицький національний природний парк, м. Галич, Украӥна

${ }^{2}$ Національний лісотехнічний університет України, м. Львів, Украйна

\title{
НАСІННА ПРОДУКТИВНІСТЬ СОСНИ КЕДРОВОЇ КОРЕЙСЬКОÏ (PINUS KORAIENSIS SIEВ. ET ZUCC.) В МЕЖАХ ГАЛИЦЬКОГО НАЦІОНАЛЬНОГО ПРИРОДНОГО ПАРКУ
}

\begin{abstract}
Наведено коротку характеристику сосни кедрової корейської та проведено історичний екскурс щодо його появи у лісових насадженнях Галицького національного природного парку (Галицький НПП). Проаналізовано сучасні напрями досліджень виду у світі та зроблено висновок щодо актуальності його досліджень в Україні, а саме: доцільність вивчення процесів шишко- та насіннєношення, які безпосередньо впливають на насінну продуктивність. Описано результати фенологічних спостережень та встановлено періодичність шишконошення виду на постійній лісонасінній ділянці у Галицькому НПП. Висвітлено результати дослідження біометричних показників шишок і насіння кедрової корейської сосни. Результати досліджень свідчать про високу насінну продуктивність інтродуцента в умовах підприємства та дають підстави висловити припущення про збільшення цього показника впродовж кількох найближчих десятиліть, одночасно зі збільшенням віку шишконосних дерев. Встановлено оптимальні терміни заготівлі лісонасінної сировини та виявлено чинник, що впливає на зменшення врожаю шишок. Висвітлено результати інвентаризації самосіву досліджуваного виду на пробних ділянках та зроблено аналіз його висотної структури. Одночасно з обліком самосіву, наведено найхарактерний місця його появи в насадженні та висунуто припущення щодо причин його масового випадання впродовж другого та третього років життя. Проведене дослідження підтвердило натуралізацію виду в умовах Галицького НПП і вказало на притаманну для нього досить високу насінну продуктивність. Результати досліджень свідчать про можливість ширшого впровадження цього цінного, для лісового господарства, виду у лісові насадження регіону.
\end{abstract}

Ключові слова: інтродукція; вид; насіння; природне поновлення.

Вступ. Інтродукція - це один із перспективних методів збагачення місцевого генофонду рослин, який дає змогу вирішувати теоретичні і практичні завдання для підбору рослинних видів із цінними господарськими ознаками (Oleksiv, \& Pytliuk, 2008; Smahliuk, 1976). Ha території Галицького НПП зосереджено велику кількість інтродукованих деревних видів, таких як: дуб червоний, ялина європейська, евкомія в'язолиста, робінія звичайна, сосна кедрова корейська, бархат амурський, сосна чорна та модрина японська.

Розмноження та відтворення інтродукованих деревних видів $\epsilon$ важливим етапом натуралізації рослин. Як відомо, розмноження деревних рослин може відбуватися двома способами: насінним та вегетативним. У природних умовах сосна кедрова корейська розмножується насінним способом, що забезпечує поширення виду в межах ареалу. В умовах інтродукції, для цінних видів важливим $€$ також і вегетативне розмноження, яке забезпечує відтворення рослин у разі, коли насіннєве розмноження неможливе (Cherniak, 2004).

Відсутність достатньої кількості садивного матеріалу цінних у господарському вимірі інтродукованих видів дерев перешкоджає впровадженню їх у лісові насадження нашої країни. Тому для розмноження госпо- дарсько-цінних екзотів, важливим є вивчення процесу насіннєношення для подальшого покращення стану заготівлі та використання насіння у розсадництві. Застосування насінного способу розмноження передбачає наявність насінної бази.

Огляд літературних джерел. Результати аналізу наукових праць, висвітлених у світовій науково-метричній базі упродовж останніх років, свідчать про зростання в наукових колах інтересу до сосни кедрової корейської. Дослідження стосувались вивчення чутливості насаджень сосни кедрової корейської до змін клімату (Joo et al., 2013), оцінювання біомаси самосіву та підросту сосни у змішаних насадженнях (Jinsong Wang et al., 2002). Щодо господарського впливу людини, вивчено, як змінюються таксаційні показники штучних лісових насаджень після проведення в них рубань різної інтенсивності (Choi et al., 2014). Встановлено важливість проведення довготривалих досліджень господарського впливу на штучні насадження кедрової корейської сосни, для розширення їх функціональності (збереження біорізноманіття, рекреаційного використання тощо) (Mason \& Zhu, 2014). Цікавими виявились результати дослідження з обрізування верхівок дерев на лісонасінних плантаціях. Вкорочення верхівок дерев проводили

\section{Інформація про авторів:}

Мандзюк Роман Іванович, канд. с.-г. наук, наук. співробітник. Email: romanmandziuk@gmail.com

Харачко Тарас Іванович, канд. с.-г. наук, доцент, кафедра лісових культур і лісової селекції. Email: taras-forester@ukr.net

Цитування за ДСтУ: Мандзюк Р. І., Харачко Т. І. Насінна продуктивність сосни кедрової корейської (Pinus Koraiensis Sieb. et Zucc.) в межах Галицького національного природного парку. Науковий вісник НЛтУ України. 2018, т. 28, № 3. С. $43-47$.

Citation APA: Mandziuk, R. I., \& Kharachko, T. I. (2018). On Seed Productivity of the Pinus Koraiensis (Sieb. et Zucc.) in Halych National Nature Park. Scientific Bulletin of UNFU, 28(3), 43-47. https://doi.org/10.15421/40280309 
для стимулювання шишконошення (Han et al., 2008). Водночас із вивченням впливу обрізування верхівок на збільшення інтенсивності появи шишок встановлено, що згадана операція практично не вплинула на хімічний склад зібраного насіння (Bae et al., 2008). В. В. Ocташенко (2014) вивчав періоди шишконошення та якість насіння сосен кедрових в умовах Далекого Сходу Російської Федерації (Ostashenko et al., 2014).

Також останніми роками увага наукової спільноти прикута до цінних властивостей хімічних речовин, які отримували 3 різних органів (зокрема із шишок та насіння) кедрової корейської сосни. Зокрема, виявлено, що отримані речовини проявляють антидіабетичний ефект (Joo et al., 2013), можуть використовуватись як природний протипухлинний агент (Lee et al., 2015; Yi et al., 2015), слугувати джерелом природних антиоксидантів (Zou et al., 2013; Zhou et al., 2015).

В Україні питання вирощування сосен кедрових у лісових культурах порушував Р. О. Яцик (2001). У своїх працях він досліджував адаптацію сосен кедрової сибірської і корейської у штучних насадженнях та вивчав ріст їх стовбурів (Yatsyk, 2001). Дослідження якості насіння сосни кедрової корейської у 2012-2013 рр. проводили у Національному ботанічному саду ім. М. М. Гришка (Boyko, Pokhylchenko \& Kushnir, 2014).

Аналізуючи літературні джерела, виявлено невеликий обсяг малу кількості інформації щодо вивчення насінної продуктивності сосни кедрової корейської в регіоні дослідження. Брак даних про місцезростання і стан насіннєносних дерев ускладнює визначення реального насінного потенціалу цінних деревних видів на теритоpiї регіону. Це свідчить про актуальність дослідження цієї проблематики і доцільність ії грунтовного вивчення.

Мета роботи - визначити насінну продуктивність сосни кедрової корейської на території Галицького національного природного парку, оцінити її насінний потенціал.

Методика дослідження. Біометричні показники шишок і насіння визначали 3 десяти дерев. Заготівлю шишок проводили шляхом обривання їх з ростучих дерев. Виконано заміри біометричних показників у свіжозібраних шишок. Вибірка дослідження становила 50 шишок. Під час дослідження біометричних показників проведено заміри довжини та діаметра шишок. Діаметр визначали на середині довжини шишки. Для визначення маси шишок проводили їх зважування на електронних вагах у свіжозібраному і сухому станах. Для зменшення вологості шишок використовували природне висушування. Для цього шишки розсипали на провітрювані сита, щоб запобігти їхньому запарюванню. Сита складали одне на одне і поміщали на відкритій території під накриттям. Також визначали загальну кількість насінин у кожній шишці; кількість виповнених i недорозвинених насінин та їхню масу.

Для визначення часу дозрівання та термінів заготівлі насінної сировини провели фенологічні спостереження шляхом фіксації щорічного утворення мегастробіл (†) та ін. фенологічних фаз, використовуючи методику Н. Є. Булигіна (Bulygin, 1979).

Перероблення насінної сировини, для отримання насіння, здійснювали шляхом механічного пошкодження шишок, при цьому визначали масу насіння 3 кожної шишки окремо (Debryniuk et al., 1998). Статистичні показники визначали за апробованою методикою (Но- roshko, Myklush \& Khomiuk, 2004). Для визначення кількості природного поновлення сосни кедрової корейської закладали пробні площадки розміром 2,0×2,0 м, кількістю 50 шт. на 1 га. Оцінювання природного поновлення проводили за методикою М. М. Горшеніна (Gorshenin \& Shvidenko, 1977).

Об'скти дослідження. Насадження із вмістом сосни кедрової корейської зростають у Галицькому НПП на території Галицького лісництва в урочищі "Водники". Ділянки заклав у 1983 р. заслужений лісівник М. Й. Кудляк. Лісові культури було створено на чорноземах опідзолених. Висота н.р.м. насаджень становить 280 м. У складі насаджень, окрім сосни кедрової корейської, також представлені модрина європейська, дуб звичайний та бук лісовий.

Дослідження проводили на постійній лісонасінній ділянці сосни кедрової корейської (кв. 20, вид. 23, площа - 3,2 га). Сучасний склад насадження на ПЛНД не змінився від початкового - 4Скдк3Дз2Бкл1Лпд. Тип лісу на досліджуваній ділянці - свіжа букова діброва $\left(\mathrm{D}_{2}\right.$ бкД), який $є$ характерний для дуба лісового, сосна кедрова корейська зростає за першим класом бонітету, маючи стовбурний запас 96,3 м². Загальний запас деревини на ділянці становить $170,0 \mathrm{~m}^{3} \cdot \mathrm{ra}^{-1}$. Підріст та підлісок на пробній ділянці майже відсутні. Розміщення дерев рівномірне. Загалом, порівнюючи сосну кедрову корейську з буком лісовим та дубом звичайним на досліджуваній ділянці, треба зазначити, що іiі дерева виглядають дещо гірше. Це помітно по середній висоті та середньому діаметру породи. Так, середня висота сосни становить 11,2 м, бука лісового - 15,8 м, дуба звичайного - 11,9 м. Середній діаметр порід на ділянці такий: сосна кедрова корейська - 22,02 см, бук лісовий 33,47 см, дуб звичайний - 16,01 см. На сьогодні сосна кедрова корейська, на досліджуваній ділянці частково випадає 3 насадження, що в подальшому вплине на зміну їі частки у складі. Це насадження належать до господарської зони парку.

Рекреаційна характеристика досліджуваних ділянок: закриті простори - деревостани горизонтальної зімкненості з другим класом естетичної оцінки. Рекреаційна оцінка середня, склад насаджень неоднорідний. Рельєф на ділянках рівнинний. Під час спостережень на одному із дерев сосни кедрової корейської зафіксовано вірусне пошкодження бруньок ("відьмина мітла"), яке супроводжується асиметричним ростом пагонів. Варто зазначити, що на території України на деревах досліджуваного виду "відьмині мітли" трапляються вкрай рідко.

Результати дослідження. Під час фенологічних спостережень відзначено одночасне проходження генеративних фаз в сосни кедрової корейської. При цьому встановлено, що кількість мегастробіл у окремих екземплярів змінювалася від 4 до 50 шт. Масове пилування мікростробіл (ठ) спостерігали раз на 2-3 роки. Зазначимо, що на деяких деревах мегастробіли не утворювалися протягом 7 років (період спостереження). У сосни кедрової корейської, як і у всіх видів роду Pinus L., мегастробіли розвиваються упродовж двох років. Для сосни кедрової корейської, в умовах інтродукції, масове шишконошення відбувається раз на 2-3 роки (рис. 1). При цьому на деяких деревах спостерігали щорічне утворення шишок, але в значно меншій кількості ніж у насінні роки. Зазначимо, що у цього виду значно пошкоджуються шишки білками, що триває зі середини 
липня і до кінця вересня. За нашими окомірними підрахунками пошкодження, шишок білками становить 30...40 \% від їх початкової кількості.

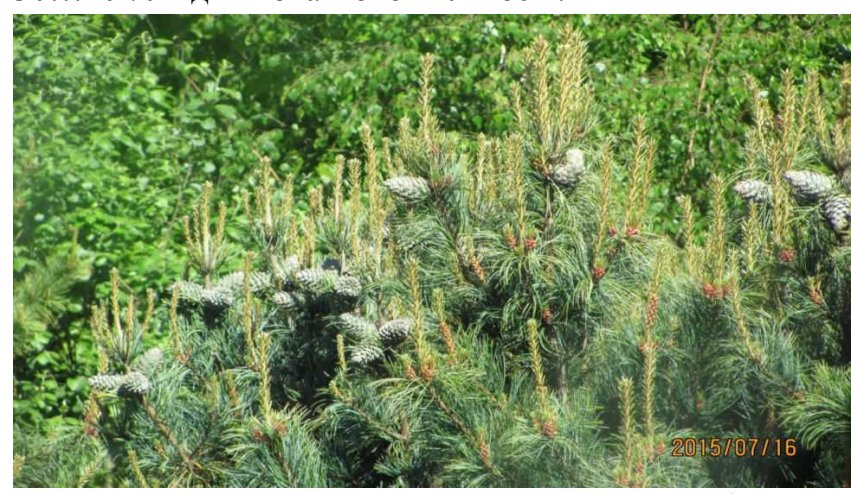

Рис. 1. Шишконошення сосни кедрової корейської насінного року
Отримані результати спостережень показали, що основна кількість дерев досліджуваного виду в насадженнях почала шишконосити у молодому віці - 20...25 років. Наявність насінних дерев молодого віку свідчить про високий потенціал насінної продуктивності дерев сосни кедрової корейської на території Галицького НПП. Для досліджень шишок, їх заготівлю починали у другій половині серпня. Середня кількість шишок на дереві становила 8-10 шт. У насіннєві роки на окремих деревах було понад 40 шт. шишок.

Відомо, що істотний вплив на розміри, кількість повнозернистого насіння та його масу має кліматичний фактор. Проте, хоча й кліматичні умови Галицького НПП відрізняються від умов природного ареалу сосни кедрової корейської, інтродуцент тут здатний утворювати шишки і формувати якісне життєздатне насіння. Дані біометричних показників наведено у табл. 1.

Табл. 1. Біометричні показники шишок сосни кедрової корейської

\begin{tabular}{|c|c|c|c|c|c|c|c|c|}
\hline \multirow{3}{*}{ Показник } & \multicolumn{4}{|c|}{ Параметри шишок } & \multicolumn{4}{|c|}{ Середня кількість та маса насінин в одній шишці } \\
\hline & \multirow{2}{*}{ довжина, мм } & \multirow{2}{*}{ товщина, мм } & \multicolumn{2}{|c|}{ Maca, $\Gamma$} & \multirow{2}{*}{ маса насіння, г } & \multicolumn{3}{|c|}{ кількість насіння, шт. } \\
\hline & & & свіжозібраних & сухих & & виповнене & недорозвинене & разом \\
\hline$\overline{L_{\min }}$ & 99,3 & 56,2 & 143,5 & 83,6 & 39,1 & 42,0 & 17,0 & $\overline{59,0}$ \\
\hline$L_{\max }$ & 172,7 & 84,5 & 493,6 & 291,7 & 154,1 & 146,0 & 60,0 & 206,0 \\
\hline$L_{c p}$ & 136,5 & 71,0 & 311,5 & 187,4 & 98,1 & 90,0 & 39,0 & 129,0 \\
\hline$\sigma^{2}$ & 560,46 & 66,01 & 11780,66 & 4090,07 & 1362,86 & 823,0 & 153,6 & 1598,38 \\
\hline$\sigma$ & 23,67 & 8,12 & 108,54 & 63,95 & 36,92 & 28,7 & 12,39 & 39,98 \\
\hline$V, \%$ & 17,35 & 11,43 & 34,84 & 34,13 & 37,64 & 31,63 & 31,26 & 30,67 \\
\hline$P, \%$ & 1,67 & 0,57 & 7,67 & 4,52 & 2,61 & 2,03 & 0,88 & 2,83 \\
\hline
\end{tabular}

Умовні позначення: $L_{\min }-$ мін. значення; $L_{\max }-$ макс. значення; $L_{c е p}-$ середнє значення; $\sigma^{2}-$ дисперсія; $\sigma$ - середнє квадратичне відхилення; $V, \%$ - коефіцієнт варіації; $P$ - точність досліду.

Насінна продуктивність одного дерева становить 10-15 кг свіжозібраних шишок. Середній вихід насіння iз шишок - 25-30 \% або 2-3 кг насіння. Маса 1000 шт. насінин - 544,03 $3^{ \pm 0,02}$ г. Отримані результати відрізняються від даних літературних джерел. Так, за даними Р. О. Яцика, 1000 шт. насінин сосни кедрової корейської мають масу 405,5 г (Jinsong Wang et al., 2002). Це, ймовірно, зумовлене отриманням даних $з$ дерев різного віку та різними умовами зростання виду.

Згідно з нашими дослідженнями, кількість недорозвиненого насіння в шишках становить $25 \ldots 35 \%$. При цьому цей показник не є стабільним для кожного року. Так, у 2014 р. кількість недорозвиненого насіння становила $10 \ldots 15 \%$, що свідчить про сприятливі умови запилення мегастробіл у 2013 р. Загалом результати дослідження свідчать про значну варіабельність маси шишок, що пов'язано 3 високою мінливістю розмірів шишок і насіння сосни кедрової корейської в умовах Галицького НПП.

Під час проведення дослідження природного поновлення сосни кедрової корейської в позаареальних умовах виявлено значну кількість іiі самосіву. Визначені біометричні показники самосіву сосни кедрової корейської на пробних площах наведено в табл. 2.

Табл. 2. Біометричні показники самосіву сосни кедрової корейської

\begin{tabular}{|c|c|c|}
\hline Динаміка за & \multicolumn{2}{|c|}{ Біометричні показники } \\
\cline { 2 - 3 } роками & висота, см & діаметр кореневої шийки, мм \\
\hline 1-річні & $5,2^{ \pm 0,05}$ & $2,3^{ \pm 0,04}$ \\
\hline 2-річні & $9,3^{ \pm 0,13}$ & $4,1^{ \pm 0,11}$ \\
\hline 3-річні & $17,4^{ \pm 0,09}$ & $6,7^{ \pm 0,16}$ \\
\hline
\end{tabular}

Варто зазначити, що значна частина самосіву припадає на однорічні рослини, а саме $80 \%$, дворічного самосіву виявлено $15 \%$, а трьох-чотирьохрічного - $5 \%$.
Це свідчить про те, що самосів з'являється практично щорічно. Значне зменшення кількості самосіву у двохтрирічному віці, на наш погляд, зумовлене низьким потраплянням сонячного світла, через проекції крон бука лісового. Однорічні рослини сони кедрової корейської на пробних площадках здебільшого випадків трапляється куртинами по 3-5 шт. (рис. 2).

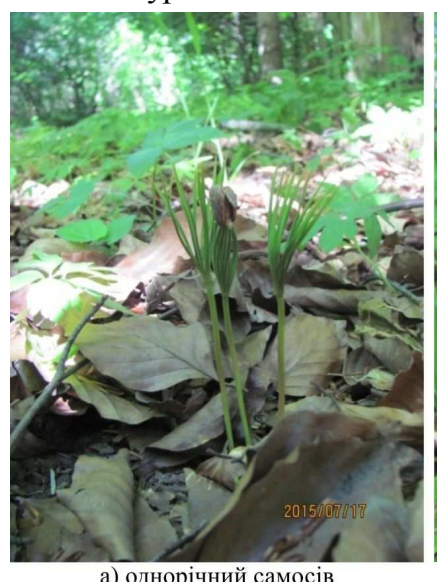

а) однорічний самосів

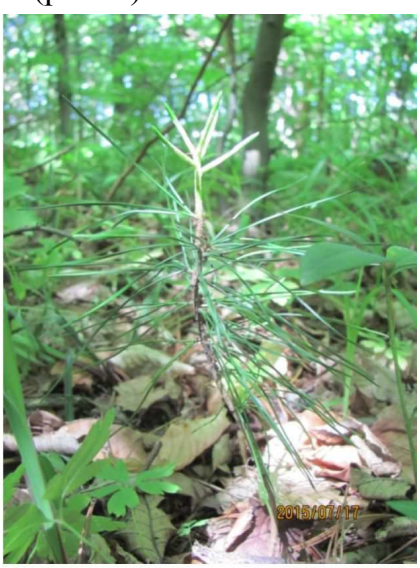

б) трирічний самосів
Рис. 2. Фрагменти облікових площадок із самосівом сосни кедрової корейської

Значний вплив на ріст і розвиток самосіву має освітлення, товщина і ступінь розкладання підстилки. У міжряддях бука міститься товстий, слаборозкладений шар підстилки, який негативно впливає на появу самосіву досліджуваної породи. На межі рядів сосни кедрової корейської з рядами дуба звичайного підстилка розкладається краще. Тут, у трав'яному вкритті, появляються осока волосиста (Carex pilosa Scop.) та анемона дібровна (Anemone nemorosa L.), що свідчить про середні умови зволоження (мезофільні). Загалом самосів на ділянках розміщений невеликими куртинами. Серед самосіву 
також трапляються бук лісовий і дуб звичайний, але їхня кількість $\epsilon$ незначною.

Висновки. Результати наших досліджень доводять, що інтродуцент добре пристосований до природно-кліматичних умов Галицького НПП та має високу насінну продуктивність (400...600 кг·га ${ }^{-1}$ свіжозібраних шишок). Середній вихід насіння із шишок $-100 \ldots 150 \kappa^{\circ} \cdot \mathrm{ra}^{-1}$.

Наявність насінних дерев сосни кедрової корейської молодого віку дає підстави стверджувати, що насінний потенціал почав розкриватися і має стійку тенденцію до збільшення. Дослідженням встановлено, що період проходження генеративних фаз відбувається одночасно. Це позитивно впливає на процес запилення і подальшу якість насіння.

Отримані результати дають змогу стверджувати, що інтродукований в лісові насадження Галицького НПП вид добре розмножується насінним способом. Цю властивість, для отримання садивного матеріалу, доцільно використовувати у лісогосподарській практиці підприємства.

Різновіковий самосів сосни кедрової корейської на території парку свідчить про те, що кліматичні та екологічні умови регіону є сприятливі для росту і розвитку досліджуваного інтродуцента. Наявність самосіву $є$ свідченням того, що досліджуваний вид є натуралізований в умовах Галицького НПП.

\section{Перелік використаних джерел}

Bae, C.-H., Song, J.-M., Kim, C.-W., Song, J.-H., Han, S.-U., Shim, T.-H., \& Yi, J.-S., (2008). Comparison of seed component between stempruned and un-pruned trees in a Pinus koraiensis seed orchard. Ann. For. Res., 51, 157-158.

Boyko, N. M., Pokhylchenko, O. P., \& Kushnir, N. V. (2014). Quality of Pinus koraiensis Sieb. et Zucc. In N. N. Gryshko NBG NASU, 2012-2013. "Biodiversity conservation and introduction of plants", (pp. 274-277). The papers of international scientific conference and schools (Kharkiv, September, 8-11, 2014). Kharkiv: Tarasenko V.P.

Bulygin, N. E. (1979). Fenologicheskie nabliudeniia nad drevesnymi rasteniiami. Leningrad: LTA. 97 p. [In Russian].

Cherniak, V. M. (2004). Kultyvovana dendroflora Volyno-Podillia, perspektyvy yii vykorystannia ta zbahachennia. Ternopil: TNPU. 264 p. [In Ukrainian].

Choi, Ju., Lee, B., Lee, D., \& Choi, I. (2014). Growth Monitoring of Korean White Pine (Pinus koraiensis) Plantation by Thinning Intensity J. Korean For. Soc., 103(3), 422-430. https://doi.org/10.14578/jkfs.2014.103.3.422

Debryniuk, Yu. M., Kalinin, M. I., Huz, M. M., \& Shablii, V. I. (1998). Lisove nasinnytstvo. Lviv: Svit. 432 p. [In Ukrainian].
Gorshenin, N. M., \& Shvidenko, A. I. (1977). Lesovodstvo. Lviv: Vishha shk. 303 p. [In Russian].

Han, S. U., Kang, K. S., Kim, C. S., Kim, T. S., \& Song, J. H. (2008). Effect of top-pruning in a clonal seed orchard of Pinus koraiensis. Ann. For. Res., 51, 155-156.

Horoshko, M. P., Myklush, S. I., \& Khomiuk, P. H. (2004). Biometriia. Lviv: Kamula. 236 p. [In Ukrainian].

Jinsong Wang, Juan Fan, Xiuhua Fan, Chunyu Zhang, L. Wu, Klaus V. Gadow. (2002). Crown and root biomass equations for the small trees of Pinus koraiensis under canopy. Dendrobiology, 70, 13-25. https://doi.org/10.12657/denbio.070.002

Joo, H. E., Lee, H. J., Sohn, E. J., Lee, M. H., Ko, H. S., Jeong, S. J, Lee, H. J., Kim, S. H. (2013). Anti-Diabetic Potential of the Essential Oil of Pinus koraiensis Leaves toward StreptozotocinTreated Mice and HIT-T15 Pancreatic $\beta$ Cells, Bioscience, Biotechnology, and Biochemistry, 77(10), 1997-2001. https://doi.org/10.1271/bbb.130254

Lee, J. H., Lee, K., Lee, D. H., et al. (2015). Anti-invasive effect of $\beta$ myrcene, a component of the essential oil from Pinus koraiensis cones, in metastatic MDA-MB-231 human breast cancer cells. $J$ Korean Soc Appl Biol Chem, 58, 563-569. https://doi.org/10.1007/s13765-015-0081-3

Mason, W. L., \& Zhu, J. J. (2014). Silviculture of Planted Forests Managed for Multi-functional Objectives: Lessons from Chinese and British Experiences. In: T. Fenning (eds) Challenges and Opportunities for the World's Forests in the 21st Century. Forestry Sciences, 81. Springer, Dordrecht

Oleksiv, T. M., \& Pytliuk, V. I. (2008). Dereva i kushchi dendroparku "Vysokohirnyi": 40-richnyi period aprobatsii. Ivano-Frankivsk: Foliant. 156 p. [In Ukrainian].

Ostashenko, V. V. Ostashenko, L. Yu., Akymov, R. Yu., \& Ostashenko, V. Yu. (2014). Rost y kachestvo semian kedrovoho stlanyka y sosnы kedrovoi koreiskoi v uslovyiakh yuha Dalneho Vostoka. Lisivnytstvo i ahrolisomelioratsiia, 125, 129-136. [In Ukrainian].

Smahliuk, K. K. (1976). Introdukovani khvoini lisoutvoriuvachi. Uzhhorod: Karpaty. 95 p. [In Ukrainian].

Yatsyk, R. O. (2001). Sosna kedrova v lisovykh kulturakh Bukovyny. Scientific Bulletin of UNFU, 11(1), 17-20. [In Ukrainian].

Yi, J., Wang, Z., Bai, H., Yu, X., Jing, J., \& Zuo, L. (2015). Optimization of Purification, Identification and Evaluation of the in Vitro Antitumor Activity of Polyphenols from Pinus Koraiensis Pinecones. Molecules, 20, 10450-10467. https://doi.org/10.3390/molecules200610450

Zhou, Y., Clark, M., Su, J., et al. (2015). Litter decomposition and soil microbial community composition in three Korean pine (Pinus koraiensis) forests along an altitudinal gradient. Plant Soil, 386, 171-183. https://doi.org/10.1007/s11104-014-2254-y

Zou, P., Yang, X., Huang, W. W, Zhao, H. T., Wang, J., Xu, R. B., Hu, X. L., Shen, S. Y., \& Qin, D. (2013). Characterization and bioactivity of polysaccharides obtained from pine cones of Pinus koraiensis by graded ethanol precipitation. Molecules, 18(8), 99339948. https://doi.org/10.3390/molecules18089933

Р. И. Мандзюк1 , Т. И. Харачко 2

${ }^{1}$ Галииякй национальный природный парк, г. Галич, Украина ${ }^{2}$ Национальный лесотехнический университет Украины, г. Львов, Украина

\section{СЕМЕННАЯ ПРОДУКТИВНОСТЬ СОСНЫ КЕДРОВОЙ КОРЕЙСКОЙ (PINUS KORAIENSIS SIEВ. ЕT ZUCC.) В ПРЕДЕЛАХ ГАЛИЦКОГО НАЦИОНАЛЬНОГО ПРИРОДНОГО ПАРКА}

Приведены краткая характеристика сосны кедровой корейской и исторический экскурс ее появления в лесных насаждениях Галицкого национального природного парка (Галицкий НПП). Проанализированы современные направления исследований вида в мире и сделан вывод об актуальности его исследований в Украине, а именно: целесообразность изучения процессов шишко- и семеноношения, которые непосредственно влияют на семенную продуктивность. Описаны результаты фенологических наблюдений и установлена периодичность шишконошения вида на постоянном лесосеменном участке в Галицком НПП. Представлены результаты исследования биометрических показателей шишек и семян кедровой корейской сосны. Результаты исследований указывают на высокую семенную продуктивность интродуцента в условиях предприятия и позволяют предположить об увеличении этого показателя в течение нескольких ближайших десятилетий, одновременно с увеличением возраста шишконосных деревьев. Установлены оптимальные сроки заготовки лесосеменного сырья и выявлен фактор, влияющий на уменьшение урожая шишек. Представлены результаты инвентаризации самосева изучаемого вида на пробных участках и сделан анализ его высотной структуры. Одновременно с учетом самосева, описаны наиболее характер- 
ные места его появления в насаждении и выдвинуто предположение о причинах его массовой гибели в течение второго и третьего годов жизни. Проведенное исследование подтвердило натурализацию вида в условиях Галицкого НПП и указало на присущую ему достаточно высокую семенную продуктивность. Результаты исследования указывают на возможность более широкого внедрения этого ценного для лесного хозяйства вида в лесные насаждения региона.

Ключевые слова: интродукция; вид; семена; естественное возобновление.

R. I. Mandziuk1, T. I. Kharachko ${ }^{2}$

${ }^{1}$ Halych National Nature Park, Halych, Ukraine

${ }^{2}$ Ukrainian National Forestry University, Lviv, Ukraine

\section{ON SEED PRODUCTIVITY OF THE PINUS KORAIENSIS (SIEB. ET ZUCC.)} IN HALYCH NATIONAL NATURE PARK

The evaluation of seed productivity of the Pinus koraiensis (Sieb. et Zucc.) for forestry enterprises involves high-quality estimation of stocking and naturalization of species. Our research was carried out in Ukraine, on P. koraiensis forest plantation in Halych National Nature Park. We use three research methods in this work: phenological - to identify phenology specifics for the beginning and the end of genesic organs phenophases; the forestry - to learn the growth of $P$. koraiensis self-seeding, and statistical to process research results. During our research we conducted analysis of scientific literature on the modern use of generative organs, seeds and species overall; on ways of increasing the cones production; on changes in plantations of $P$. koraiensis, that take place simultaneously with the climate change. Moreover, during the study we found that the number of megastrobil among some specimens varied from 4 to 50 pcs. We have renealed that megastrobils had not been formed for 7 years on separate trees. We have also defined biometric indices of cones and seeds. Thus, the length of the pine cones of the P. koraiensis ranges from $99.3 \mathrm{~mm}$ to $172.7 \mathrm{~mm}$, with the average length of the cones $136.5 \mathrm{~mm}$, the thickness (diameter) ranges from 56.2 to $84.5 \mathrm{~mm}$. The weight of one fresh cone varies from 143.5 to $493.6 \mathrm{~g}$. The average yield of seeds from one cone is $98.1 \mathrm{~g}$. The maximum number of seeds in one cone was 206 pcs. the minimum - 59 pcs. The weight of 1000 pieces is $544.03^{ \pm 0} .02 \mathrm{~g}$. In addition to that we provided biometric characteristics for the introducent's self-seeding. It has been established that a significant part of self-seeding belongs to annual plants, namely $80 \%$, two-year self-seeding take $15 \%$, and three-four-year olds $5 \%$ respectively. It was found that annuals of $P$. koraiensis plants at small test sites occur in small curtains of 3-5 pcs. The plant is well adapted to climate conditions of the enterprise and has high seed productivity. Uneven-aged self-seeding of $P$. koraiensis on the territory of the enterprise means that climate and environmental conditions of the region are favourable for the growth and development of the plant. Moreover, the presence of selfseeding proves the fact that the studied species are naturalized in the conditions of Halych National Nature Park.

Keywords: introduction; species; seed; natural renewal. 